\title{
Three Electrode Electrochemical Microfluidic Cell: Construction and Characterization
}

\author{
Rodrigo A. B. da Silva, Edimar G. N. de Almeida, Adriano C. Rabelo, \\ Abílio T. C. da Silva, Lucas F. Ferreira and Eduardo M. Richter*
}

Instituto de Química, Universidade Federal de Uberlândia, Av. João Naves de Ávila, 2121, CP 593, 38400-902 Uberlândia-MG, Brazil

\begin{abstract}
Este trabalho descreve a construção e caracterização de uma célula eletroquímica microfluídica com a inserção dos três eletrodos (trabalho, pseudo-referência e auxiliar) em microcanais com espessuras menores que $20 \mu \mathrm{m}$. Os microcanais foram construídos entre duas bases de policarbonato com o uso de uma ou mais máscaras de toner sobrepostas como espaçador. Esta estratégia permite a construção de microcélulas com um volume interno sobre o eletrodo de trabalho entre 0,6 a 2,4 $\mu \mathrm{L}$. Três diferentes materiais foram otimizados como eletrodos nas microcélulas: filmes de ouro ou compósito de grafite como eletrodo de trabalho, compósito de prata como pseudo-referência e compósito de grafite como eletrodo auxiliar. O desempenho das células microfluídicas foi avaliado usando as técnicas de voltametria cíclica, redissolução potenciométrica a corrente constante e voltametria de redissolução anódica por onda quadrada empregando ferrocianeto e alguns metais pesados $\left(\mathrm{Cu}^{2+}, \mathrm{Hg}^{2+}, \mathrm{Pb}^{2+}, \mathrm{e} \mathrm{Cd}^{2+}\right)$ como analitos modelo.
\end{abstract}

This work describes the construction and characterization of an electrochemical flow-through microcell with the three electrodes (working, pseudo-reference, and auxiliary) inserted in microchannels with thickness smaller than $20 \mu \mathrm{m}$. These microchannels were constructed between two stacked polycarbonate slides using one or more overlapped toner masks as spacer. This strategy allows the construction of microcells with a variable internal volume on the working electrode (0.6 to $2.4 \mu \mathrm{L}$ ). Three different materials were optimized as electrodes: gold film or graphiteepoxy composite as working electrode, silver-epoxy composite as pseudo-reference electrode and, graphite-epoxy composite as auxiliary electrode. The performance of the microfluidic cell was characterized by cyclic voltammetry, potentiometric stripping analysis at constant current, and square wave anodic stripping voltammetry using ferrocyanide and heavy metals $\left(\mathrm{Cu}^{2+}, \mathrm{Hg}^{2+}\right.$, $\mathrm{Pb}^{2+}$, and $\left.\mathrm{Cd}^{2+}\right)$ as model analytes.

Keywords: microfluidic cell, microchannels, gold film, graphite-epoxy composite, silverepoxy composite, pseudo-reference

\section{Introduction}

The development of miniaturized analytical systems is a subject that has been arousing a great deal of interest of the scientific community in the area of analytical chemistry. The interest is due to many reasons, among them we may point out the reduction in production costs of each system, energy consumption, samples, reagent and residue generated by analysis. ${ }^{1}$

A considerable number of articles that approaches this subject can be located in the literature (Web of Science). Using keywords such as "microfabrication or miniaturization or microchip or microfluid or microdevice" and directing the

*e-mail: emrichter@iqufu.ufu.br search only for the title, a number of 6.149 works are listed. Narrowing the search adding to the Field address the word "Brazil", the number reduces to only 24 works making up about $0.39 \%$ of the total, a number five times smaller than the mean of Brazilian contribution (superior to $2 \%$ ). This is due, mainly, to the implementation costs of laboratories that dominate the conventional microfabrication technology, such as high resolution photolitography. ${ }^{1}$ In Brazil, there are few laboratories with the available infrastructure for microdevices fabrication using these techniques. The Laboratório Nacional de Luz Síncrotron (LNLS), located in Campinas/SP/Brazil is one of the rare examples where this infrastructure is available (http://www.lnls.br).

Among the works produced in Brazil in the area of devices miniaturization or analytical systems, a considerable number 
is derived from researches which use alternative methods of microfabrication. In this context, a work that may be considered pioneer in Brazil was published by do Lago et al. ${ }^{2}$ In this paper, a process of direct deposition of toner on polyester transparency (LaserJet printer) was described for microdevices production with application in electrophoretic separations and electrospray generation. Later, Daniel and Gutz, ${ }^{3}$ using the direct-printing process described by do Lago et al. ${ }^{2}$ and gold surfaces obtained from gold CD-Rs ${ }^{4}$ demonstrated the possibility of gold electrode construction with different sizes using the heat-transference of toner on gold surfaces. The gold electrodes produced by this procedure are inserted in microchannels with a thickness of some micrometers ( $c a .20)$, with the reference and counter electrodes positioned outside the microcell. After publication of these works, a number of new applications were presented in the literature based on this procedure. Some examples are: construction of amperometric microdetectors for conventional capillary electrophoresis system ${ }^{5}$ and separation microsystems manufactured in polyester toner, ${ }^{6}$ microfluidic cells with interdigitated array gold electrodes, ${ }^{7}$ generator-collector electrochemical microdevices, ${ }^{8-10}$ production of microchannels in glass, ${ }^{11,12}$ microfluidics devices for sample treatment, ${ }^{13,14}$ new procedures for flow rate control and sample injection in microfluidic cells, ${ }^{15}$ microelectrode arrays, ${ }^{16}$ electrodes with reproducible area, ${ }^{17}$ integration of planar electrodes for contactless conductivity detection on polyester-toner electrophoresis microchips, ${ }^{18}$ insertion of passive micromixers in microfluidic devices ${ }^{19}$ and construction of electrochemical microcells containing the working, counter and reference electrodes in the same device. ${ }^{20}$

In this work a simple methodology for the construction of flow through microcells with introduction of the three electrodes (working, counter and pseudo-reference) in microchannels is described. Two configurations of microcells are presented. In the first, the working electrode inserted in the microchannel is a thin gold film while in the second it is graphite composite. In both cases, the pseudo reference and auxiliary electrodes are constituted of silver and graphite composite, respectively. The potentiality of the devices was evaluated by analyses of model analytes, resulting in similar results to those obtained with conventional electrochemical cells.

\section{Experimental}

\section{Solutions and reagents}

All solutions were prepared with deionized water (resistivity $=18 \mathrm{M} \Omega \mathrm{cm}$ ) obtained by MilliQ.plus
(Millipore) purification system. The solutions were prepared with analytical grade reagents (Merck or AnalytiCals). A solution containing $0.5 \mathrm{~mol} \mathrm{~L}^{-1} \mathrm{KCl}$ and $6.0 \mathrm{mmol} \mathrm{L}^{-1} \mathrm{HCl}$ was used as supporting electrolyte for simultaneous analysis of copper and mercury. Cadmium and lead analysis were carried out using $0.1 \mathrm{~mol} \mathrm{~L}^{-1}$ acetate buffer ( $\mathrm{pH} 4.7$ ) containing $2.0 \mathrm{mg} \mathrm{L}^{-1}$ of bismuth (formation of film in situ) as supporting electrolyte. ${ }^{21}$ In the studies with potassium ferricyanide, the supporting electrolyte was $0.1 \mathrm{~mol} \mathrm{~L}^{-1}$ of $\mathrm{KCl}$.

The procedure for the graphite composite fabrication was the following: (i) $0.1 \mathrm{~g}$ of Epoxy resin (Araldite $^{\circledR}$ $24 \mathrm{~h}$, Brascola) was added to $3.0 \mathrm{~mL}$ cyclohexanone under stirring (5 min); (ii) Next, slowly (10 min) and under constant stirring, $0.1 \mathrm{~g}$ of poliaminoamide was added; (iii) Finally, $2.0 \mathrm{~g}$ of graphite powder (Aldrich, particles diameter, 1-2 $\mu \mathrm{m}$ ) was slowly added, keeping the mixture under stirring for $24 \mathrm{~h}$.

Before use, the graphite composite was painted on the surface of interest and cured at room temperature (about 24 h). The silver glue (PC 9045) used in this work was obtained from Joint Metal Comércio Ltda company (Diadema/SP).

\section{Instrumentation and flow system}

The electrochemical experiments were performed using a $\mu$-Autolab Type III (Eco Chemie) potentiostat, interfaced with a microcomputer and controlled by GPES 4.9 software. To print and to perform the heat transference of the toner masks, a printer HP LaserJet 1160 and a thermal press model Prima (Ferragini Design) were used, respectively. For the hydrodynamic experiments using techniques, such as potentiometric stripping analysis at constant current, square-wave anodic stripping voltammetry and cyclic voltammetry, the flow rate was controlled using a constant pressure generated by an aquarium pump. The air from the pump was bubbled into a water column connected to a closed mini bottle containing the carrier electrolyte. This artifice minimizes flow pulsation, a very important issue in experiments using microdevices with electrochemical detection..$^{22}$ The pressure generated by the system is transferred to a mini bottle and consequently the solution is pushed to the microcell through the fused silica capillary tubing with $250 \mu \mathrm{m}$ of internal diameter. To change sample or standard solution, only the body of mini bottle is substituted, the top remain in place. Stripping analysis was performed without flow stop (without pulsation). A miniaturized $\mathrm{Ag} / \mathrm{AgCl}$, sat. $\mathrm{KCl}$ was used as a conventional reference electrode. ${ }^{23}$ 
Construction of microcell using gold film as working electrode

Figure 1 shows the fabrication process of the microcell using a gold film as working electrode, graphite composite as counter electrode and silver composite as pseudoreference electrode. The process follows the next steps: (A) The image of the toner mask (spacer) is drawn at 1:1 scale using graphic software. Then, it is printed using an HP LaserJet 1160 series on a waxed paper of the type used as support (base material) for self adhesive labels. This mask defines the width and height of the microchannel. The width $(5.0 \mathrm{~mm})$ is defined by the toner-free area in the center of mask and the height by the toner thickness. The height of the microchannel is controlled by the following way: one mask $c a .6 \mu \mathrm{m}$; two overlapping masks $c a .12 \mu \mathrm{m}$; three masks $c a .17 \mu \mathrm{m}$; four masks $c a .22 \mu \mathrm{m}$. Previous studies have demonstrated that it is possible to reach $45 \mu \mathrm{m}$ of height. ${ }^{7,8,10}$ (B) Using the same procedure described in (A), another mask that defines the positioning of counter and pseudo reference electrodes, as well as the orifice of inlet and outlet of the solution is drawn. The mask, once printed, is heat transferred to a polycarbonate substrate, obtained from recordable CDs (after removal of the silver film). The orifices are made at the positions exactly indicated by the mask; $0.9 \mathrm{~mm}$ of diameter for the solution inlet, counter and pseudo-reference electrodes. The diameter of the orifice for the solution outlet is $2 \mathrm{~mm}$. (C) The polycarbonate substrate (with orifices) is polished with water sandpaper (grade 600) to remove possible imperfections generated during the drilling process. The intermediate orifices are filled, one with graphite composite and the other with silver composite, to use as counter and reference electrodes, respectively. These composites need to be dried at room temperature for $24 \mathrm{~h}$. A new polishing step is necessary to ensure a flat surface. (D) Heat transference of the toner mask described in step (A) to the substrate described in step (C). (E) Polycarbonate substrate covered partially with a thin gold film. This substrate is obtained in agreement with procedures described previously., ${ }^{3,5}$ (F) Junction (by heating) of substrates described in steps (D) and (E). The gold electrode must be positioned between and in front (opposed side) of the silver and graphite composite electrodes. To reinforce the structure of the microdevice, an epoxy adhesive (Araldite ${ }^{\circledR} 10 \mathrm{~min}$ ) is used to cover the microdevice body. (G) With the same epoxy adhesive, micro-tips are glued to the inlet and outlet sides. At the inlet side, a fused silica capillary tubing with $250 \mu \mathrm{m}$ of internal diameter is immobilized. At the outlet side, polycarbonate tubes having greater internal diameters may be used. (H) Fixation of copper wires, using the graphite or silver conductor composite, are employed to allow the electric contact between electrodes and the potentiostat.
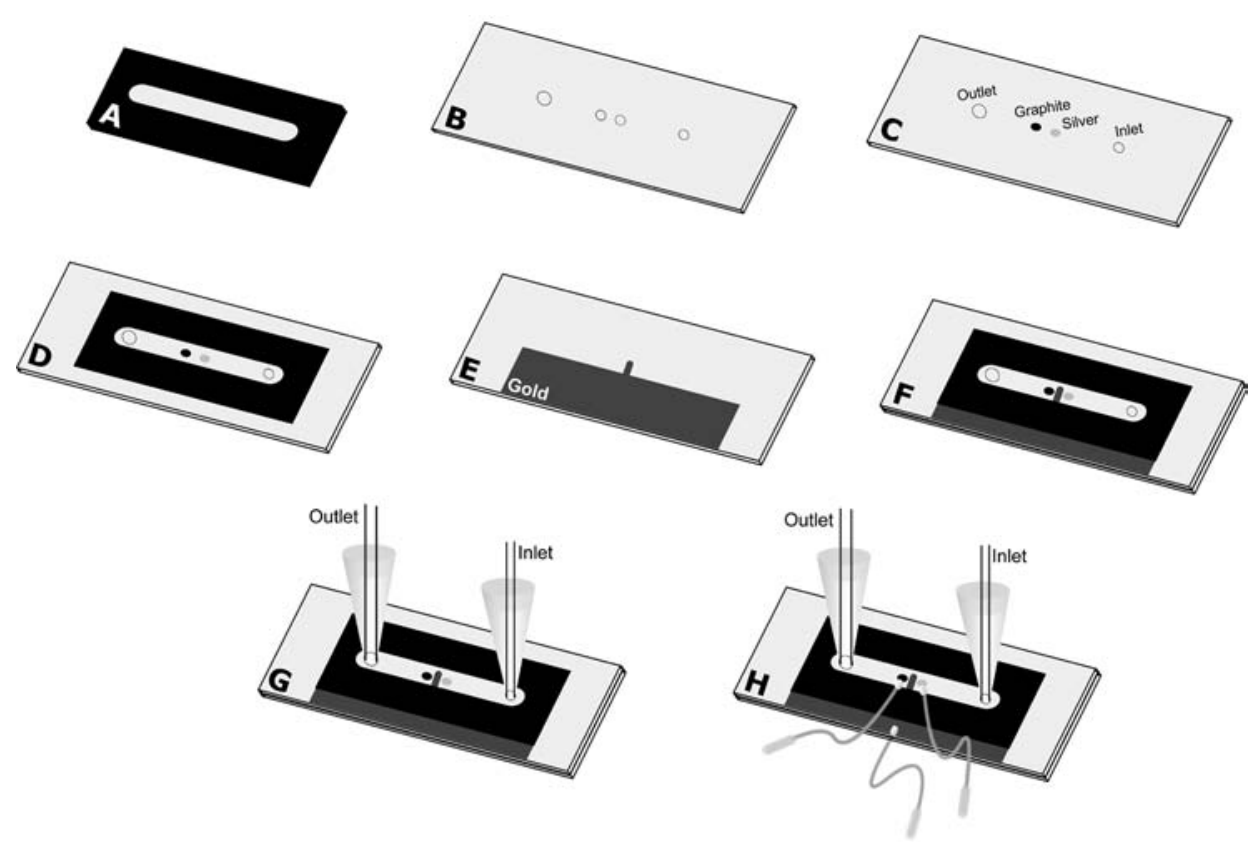

Figure 1. Steps involved in the construction of the microfluidic cell with insertion in the microchannel of a gold film, graphite composite and silver composite used, respectively, as working, counter and pseudo-reference electrode. (A) Toner mask (spacer); “(B) Transfer of a second toner mask on one polycarbonate substrate (defines the positioning of the electrodes and inlet and outlet of the solution); (C) Polycarbonate substrate with orifices. The intermediate orifices were covered with silver and graphite composite; (D) Heat transference of the toner mask described in step (A) to the substrate described in step (C); (E) Polycarbonate substrate covered partially with a thin gold film; (F) Junction (by heating) of substrates described in steps (D) and (E); (G) Micro-tips are glued to the inlet and outlet sides; (F) Fixation of copper wires. 


\section{Construction of microfluidic cell using graphite composite as working electrode}

Figure 2 shows the steps involved in the construction of a microfluidic cell when the gold working electrode (Figure 1) is substituted by graphite. Many steps of the construction are identical to the ones shown in Figure 1, as follows. (I) Acquisition of a polycarbonate substrate from a common CD-R. Implementation of three orifices: for solution inlet $(\varnothing=0.9 \mathrm{~mm})$, outlet $(\varnothing=2.0 \mathrm{~mm})$ and, the third one (intermediary; $\varnothing=0.9 \mathrm{~mm}$ ) for the introduction of the graphite composite (working electrode). (II) In another polycarbonate substrate, two orifices $(\varnothing=0.9 \mathrm{~mm})$ are drilled side by side. One is filled with graphite composite (counter electrode) and another with silver composite (pseudo reference). After polishing, the same toner mask used in the Figure 1A is heat-transferred to this substrate. (III) Join ("sandwich") the two substrates (I and II) by heating using a thermal press. The other steps (use of epoxy adhesive to mechanic reinforcement, fixation of micro-tips and electric contact) are the same as that one shown in Figure 1.

\section{Results and Discussion}

The microfluidic cell described in Figure 1 (with two toner layers overlapped as spacer) was characterized by cyclic voltammetry using potassium ferrocyanide as model analyte and $\mathrm{KCl}$ as supporting electrolyte. The performance of the pseudo-reference electrode (silver composite localized in one orifice at the upper side of the microcell) was characterized comparing the signals obtained when the pseudo-reference electrode was substituted by a conventional reference electrode $(\mathrm{Ag} / \mathrm{AgCl}, \mathrm{KCl}$ sat. $){ }^{23}$ In this case, the micro-tip located at the outlet side of the microcell was substituted by a small reservoir with $1.5 \mathrm{~mL}$ capacity, where the conventional reference electrode was inserted. Figure 3 shows the obtained results.

As we can observe in Figure 3, using stationary (3A) or hydrodynamic (3B) cyclic voltammetry, a displacement occurs in the peaks potentials of the iron(II)/iron(III) redox couple to negative potentials when the pseudo-reference silver composite electrode (I) is used in substitution to the conventional reference electrode (II). This is in agreement with previous studies. ${ }^{20}$ Moreover, the performance of the microfluidic cell was better when the pseudo reference electrode was used (located inside the microchannel), both with respect to sensibility and reversibility of the redox couple (ferro/ferricyanide). For cyclic voltammograms conducted in the stationary mode (Figure 3A), the total current measured changed from 5.83 to $8.75 \mu \mathrm{A}$, when the conventional reference electrode was substituted by the silver composite pseudo-reference electrode. This represents an increase of $50 \%$ in the faradaic current. Another significant improvement is observed in the difference between the cathodic and anodic peak potentials, $\Delta \mathrm{E}$, which changed from 180 to $45 \mathrm{mV}$ when the conventional reference electrode, positioned outside the microchannel, was substituted by silver composite pseudo-reference electrode (positioned in the interior of the microchannel). The use of the silver composite pseudo-reference electrode inside the microchannel reduces significantly the distance between the working and reference electrodes and, consequently, the resistance between them.

Cyclic voltammetry studies conducted in the stationary mode when compared to the results obtained in the hydrodynamic mode (Figure 3B), revealed the microcell performance using a silver composite pseudo-reference electrode presents better response when compared with the conventional reference electrode, showing an increase of
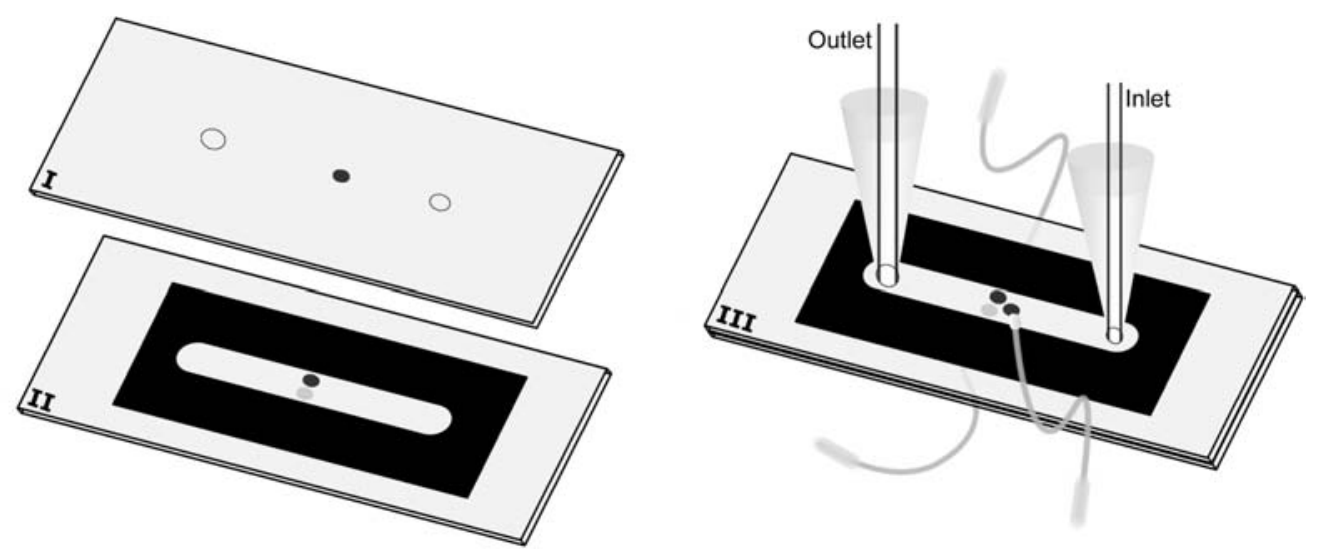

Figure 2. Steps involved in the construction of microfluidic cell with insertion in the microchannel of two graphite composites (working and counter electrodes) and silver composite (pseudo-reference electrode). 

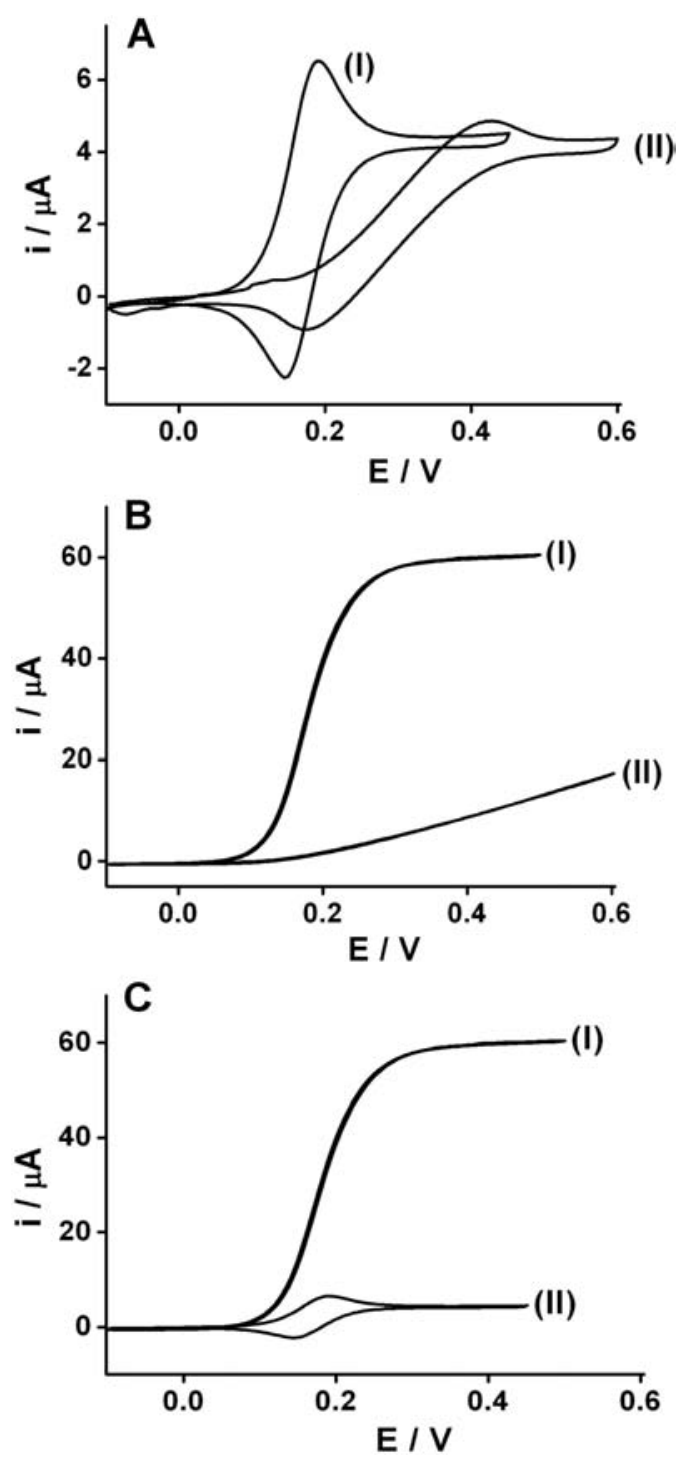

Figure 3. Cyclic voltammograms recorded in $1 \mathrm{mmol} \mathrm{L}^{-1}$ potassium ferrocyanide and $0.1 \mathrm{~mol} \mathrm{~L}^{-1} \mathrm{KCl}$. (A) Voltammograms recorded in the stationary mode using (I) silver composite positioned inside the microchannel as pseudo-reference electrode or (II) $\mathrm{Ag} / \mathrm{AgCl}$ (sat. in $\mathrm{KCl})^{23}$ positioned out of the microchannel; (B) idem to previous item (A), however under hydrodynamic conditions, $60 \mu \mathrm{L} \mathrm{min}^{-1}$; (C) Comparison between the sensibility obtained in (I) hydrodynamic and (II) stationary mode. Working electrode: gold film; Counter electrode: graphite composite. Scan rate: $50 \mathrm{mV} \mathrm{s}^{-1}$.

the faradaic current of $350 \%$ (17.1 to $60.2 \mu \mathrm{A})$. Moreover, the distortion of the voltammogram in the hydrodynamic mode (under constant flow rate) using the conventional reference electrode, was greater than the stationary cyclic voltammetry. The improvement of sensibility and reversal behavior of the system can be attributed to the fact that the silver composite pseudo-reference, which is positioned inside the microchannel near to the working and counter electrodes, generates a smaller resistance resulting in a smaller ohmic drop. This is a reasonable explanation considering that the distance between the working and reference electrodes increases significantly when it is positioned outside of the microchannel. It is important to remember that a distance up to $1.0 \mathrm{~cm}$ between electrodes in a conventional cell is acceptable because of the volume of solution (contact area) between the electrodes, which is quite different from the microdevice when the electrodes are inserted into microchannels with one of the dimensions smaller than $20 \mu \mathrm{m}$.

The use of hydrodynamic flow improves significantly the detection limit of the analytical methodologies when electrochemical techniques are used. This feature represents an important aspect when electrochemical microcells are used, when reduced volumes of solution are in contact with the working electrode (in order of nanoliters). This behavior is illustrated in Figure 3C, where the results of cyclic voltammetric experiments, using $1.0 \mathrm{mmol} \mathrm{L}^{-1}$ potassium ferrocianide as model analyte, in hydrodynamic (I) and stationary mode (II), are compared. The current signal in the hydrodynamic mode (flow rate $=60 \mu \mathrm{L} \mathrm{min}^{-1}$ ) is 7 times higher than in the stationary mode (8.7 to $60.2 \mu \mathrm{A}$ ).

Other experiments to verify the potentiality of the constructed microfluidic cell using two toner layers as spacer $(c a .12 \mu \mathrm{m})$ aiming at the quantification of heavy metals, such as copper and mercury, were conducted. The option for these ions as model analytes is supported by the potentiality of the gold working electrode used in the microcell to analyze these metals, as described in the literature. ${ }^{24,25}$ Figure 4 presents the signals obtained for the simultaneous analysis of copper and mercury using potentiometric stripping analysis at constant current as function of the increasing concentrations of both metals $\left(10,20,30,40\right.$ and $\left.50 \mu \mathrm{g} \mathrm{L}^{-1}\right)$. These chronopotentiograms were recorded using a flow rate of $60 \mu \mathrm{L} \mathrm{min}{ }^{-1}$ and deposition time of $60 \mathrm{~s}$. A comparison between the performance of the flow-through microcell with a conventional flow-through cell ${ }^{26}$ shows a similar sensitivity for both cases, however, the flow rate necessary for the conventional cell to present the same response

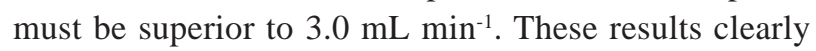
evidence that the use of the microcell permits an economy of reagents and samples of up to 50 times, decreasing the generation of residues of the same magnitude. Using a microcell with the microchannel defined by one toner mask ( $6 \mu \mathrm{m}$ of thickness) obviously reduces further, the consumption of samples and/or reagents, however, also increases the difficulty to operate the microcell.

The characterization of the microcell with a graphite composite working electrode inserted in the microchannel (4 toner masks overlapped as spacer) was done using cadmium and lead as model analytes in $0.1 \mathrm{~mol} \mathrm{~L}^{-1}$ acetate buffer and $2 \mathrm{mg} \mathrm{L}^{-1}$ of bismuth (in situ thin film formation). 


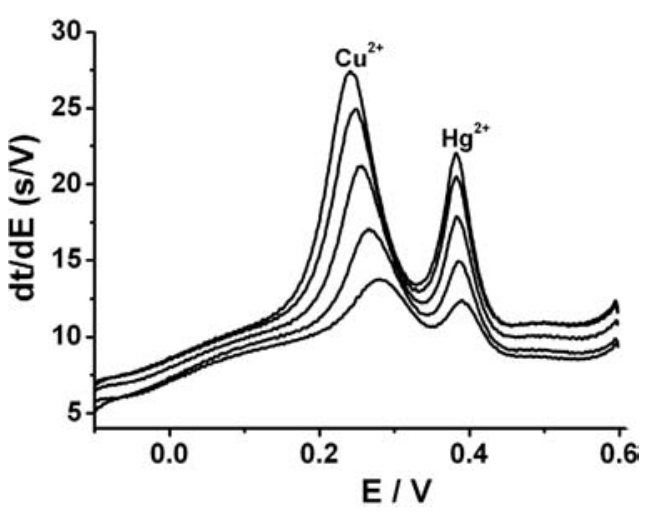

Figure 4. Signals obtained using potentiometric stripping analysis at constant current as function of increasing copper and mercury concentrations $\left(10,20,30,40\right.$ and $\left.50 \mu \mathrm{g} \mathrm{L}^{-1}\right)$ in $0.5 \mathrm{~mol} \mathrm{~L}^{-1} \mathrm{KCl}$ and $6.0 \mathrm{mmol} \mathrm{L}{ }^{-1} \mathrm{HCl}$. Deposition time: $60 \mathrm{~s}$; Deposition potential: $-0.1 \mathrm{~V}$; Constant current: $1 \mu \mathrm{A}$; Flow rate: $60 \mu \mathrm{L} \mathrm{min}{ }^{-1}$; Correlation coefficients $(\mathrm{Cu}=0.997$ and $\mathrm{Hg}=0.995)$.

Figure 5A shows the signals obtained by square wave anodic stripping voltammetry as function of the $\mathrm{Cd}^{2+}$ and $\mathrm{Pb}^{2+}$ concentration $\left(10,16,20,30,50\right.$ and $\left.100 \mu \mathrm{g} \mathrm{L}^{-1}\right)$. Linear regression equation were $\mathrm{I}_{\mathrm{pa}}(\mu \mathrm{A})=-0.0614+$ $0.0453 \mathrm{C}(\mu \mathrm{g} \mathrm{L}-1)$ and $\mathrm{I}_{\mathrm{pa}}(\mu \mathrm{A})=-0.0068+0.0331 \mathrm{C}\left(\mu \mathrm{g} \mathrm{L}{ }^{-1}\right)$ for $\mathrm{Cd}^{2+}$ and $\mathrm{Pb}^{2+}$, respectively, with a correlation coefficient of $\mathrm{r}=0.996$ for both analytes. The detection limit $(\mathrm{S} / \mathrm{N}=3)$ were 0.38 and $0.74 \mu \mathrm{g} \mathrm{L}-1$ for $\mathrm{Cd}^{2+}$ and $\mathrm{Pb}^{2+}$, respectively. Figure 5B shows the results of a reproducibility study for repetitive analysis of solutions containing $50 \mu \mathrm{g} \mathrm{L} \mathrm{L}^{-1}$ of $\mathrm{Cd}^{2+}$ and $\mathrm{Pb}^{2+}(\mathrm{n}=8)$. The relative standard deviation calculated was around $1.0 \%$ for both analytes. The use of silver composite as pseudo-reference electrode did not cause a significant variation in the peak potential for both analytes, confirming the good performance of this material for this application.

\section{Conclusions}

In this work we report a simple and easy procedure to construct microfluidic electrochemical cells with three electrodes inserted inside a microchannel that compose a voltammetric cell. In the construction process of these microdevices, inexpensive materials are used, such as: policarbonate substrates obtained from recordable compact discs (covered or not with a thin gold layer), LaserJet printer, thermal press, epoxy adhesive, graphite powder and silver composite. Due to the low production costs of each microcell, one can consider this as a construction process for disposable devices. Despite the use of alternative and low cost materials, the results obtained using this microdevice presents good potentiality for heavy metals analysis, like $\mathrm{Cu}^{2+}, \mathrm{Hg}^{2+}, \mathrm{Cd}^{2+}$ and $\mathrm{Pb}^{2+}$ at trace levels with low consumption of reagents and samples.
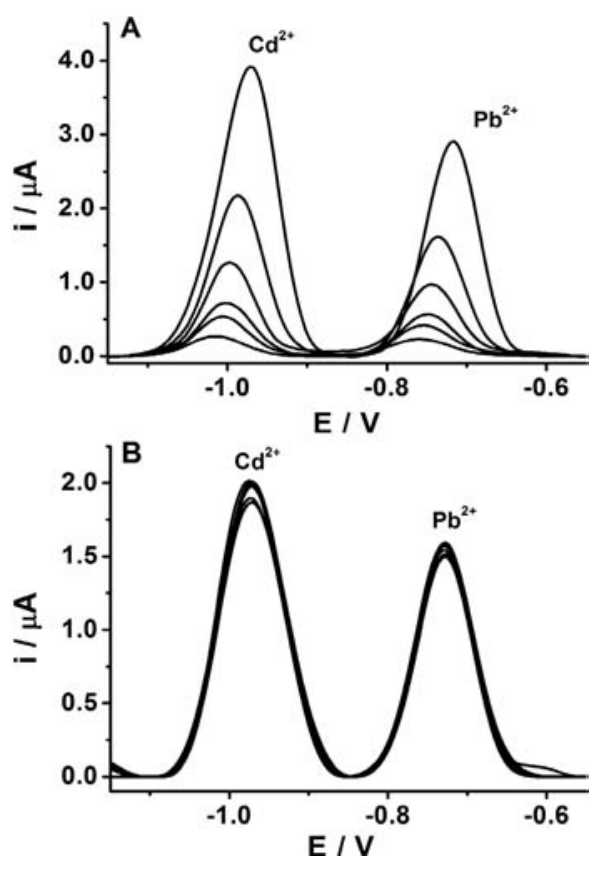

Figure 5. Signals obtained using square wave anodic stripping voltammetry in $0.1 \mathrm{~mol} \mathrm{~L}^{-1}$ acetate buffer and $2.0 \mathrm{mg} \mathrm{L}^{-1}$ of bismuth (pH 4.7). Deposition time: $180 \mathrm{~s}$; Deposition potential: $-1.7 \mathrm{~V}$; Flow

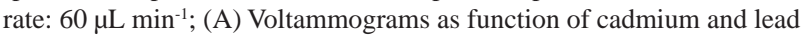
concentrations (10, 16, 20, 30, 50 and $\left.100 \mu \mathrm{g} \mathrm{L}^{-1}\right)$; Correlation coefficients $(\mathrm{Cd}=\mathrm{Pb}=0.996)$; (B) Repetitive voltammograms obtained for $50 \mu \mathrm{g} \mathrm{L}^{-1}$ of $\mathrm{Cd}^{2+}$ and $\mathrm{Pb}^{2+}$. Relative standard deviation: $1.0 \%(\mathrm{n}=8)$.

\section{Acknowledgments}

The authors thank the Fundação de Apoio à Pesquisa do Estado de Minas Gerais (FAPEMIG), the Coordenação de Aperfeiçoamento de Pessoal de Nível Superior (CAPES) and the Conselho Nacional de Desenvolvimento Científico e Tecnológico (CNPq) for financial support and Dr. Julien F. C. Boodts for the English revision.

\section{References}

1. Coltro, W. K. T.; Piccin, E.; Carrilho, E.; de Jesus, D. P.; Fracassi da Silva, J. A.; Torres da Silva, H. D.; do Lago, C. L.; Quim. Nova 2007, 30, 1986.

2. do Lago, C. L.; da Silva, H. D. T.; Neves, C. A.; Brito-Neto, J. G. A.; da Silva, J. A. F.; Anal. Chem. 2003, 75, 3853.

3. Daniel, D.; Gutz, I. G. R.; Electrochem. Commun. 2003, 5, 782.

4. Angnes, L.; Richter, E. M.; Augelli, M. A.; Kume, G. H.; Anal. Chem. 2000, 72, 5503.

5. Richter, E. M.; da Silva, J. A. F.; Gutz, I. G. R.; do Lago, C. L.; Angnes, L.; Electrophoresis 2004, 25, 2965.

6. Coltro, W. K. T.; da Silva, J. A. F.; da Silva, H. D. T.; Richter, E. M.; Furlan, R.; Angnes, L.; do Lago, C. L.; Mazo, L. H.; Carrilho, E.; Electrophoresis 2004, 25, 3832. 
7. Daniel, D.; Gutz, I. G. R.; Talanta 2005, 68, 429.

8. Paixao, T.; Richter, E. M.; Brito-Neto, J. G. A.; Bertotti, M.; Electrochem. Commun. 2006, $8,9$.

9. Ferreira, T. L.; Paixao, T.; Richter, E. M.; El Seoud, O. A.; Bertotti, M.; J. Phys. Chem. B 2007, 111, 12478.

10. Paixao, T.; Richter, E. M.; Brito-Neto, J. G. A.; Bertotti, M.; J. Electroanal. Chem. 2006, 596, 101.

11. do Lago, C. L.; Neves, C. A.; de Jesus, D. P.; da Silva, H. D. T.; Brito-Neto, J. G. A.; da Silva, J. A. F.; Electrophoresis 2004, 25, 3825 .

12. Coltro, W. K. T.; Piccin, E.; da Silva, J. A. F.; do Lago, C. L.; Carrilho, E.; Lab Chip 2007, 7, 931.

13. de Jesus, D. P.; Blanes, L.; do Lago, C. L.; Electrophoresis 2006, 27, 4935.

14. Daniel, D.; Gutz, I. G. R.; Electrochem. Commun. 2007, 9, 522.

15. Daniel, D.; Gutz, I. G. R.; Anal. Chim. Acta 2006, 571, 218.

16. Richter, E. M.; Munoz, R. A. A.; Bertotti, M.; Angnes, L.; Electrochem. Commun. 2007, 9, 1091.
17. Lowinsohn, D.; Richter, E. M.; Angnes, L.; Bertotti, M.; Electroanalysis 2006, 18, 89.

18. Coltro, W. K. T.; da Silva, J. A. F.; Carrilho, E.; Electrophoresis 2008, 29, 2260.

19. Liu, A. L.; He, F. Y.; Wang, K.; Zhou, T.; Lu, Y.; Xia, X. H.; Lab Chip 2005, 5, 974.

20. Ferreira, H. E. A.; Daniel, D.; Bertotti, M.; Richter, E. M.; J. Braz. Chem. Soc. 2008, 19, 1538.

21. Kefala, G.; Economou, A.; Voulgaropoulos, A.; Sofoniou, M.; Talanta 2003, 61, 603.

22. dos Santos, W. T. P.; Ceolin, M. P.; de Albuquerque, Y. D. T.; Richter, E. M.; Quim. Nova 2007, 30, 1754.

23. Pedrotti, J. J.; Angnes, L.; Gutz, I. G. R.; Electroanalysis 1996, $8,673$.

24. Jena, B. K.; Raj, C. R.; Anal. Chem. 2008, 80, 4836.

25. Augelli, M. A.; Munoz, R. A. A.; Richter, E. M.; Cantagallo, M. I.; Angnes, L.; Food Chem. 2007, 101, 579.

26. Richter, E. M.; PhD Thesis, Universidade de São Paulo, São Paulo, Brazil, 2004. (www.teses.usp.br/teses/disponiveis/46/46133/ tde-26092006-114024/) 